\title{
Viability of Molds and Bacteria in Tempeh Processed with Supercritical Carbon Dioxides during Storage
}

\author{
Maria Erna Kustyawati $\mathbb{D}^{1},{ }^{1}$ Filli Pratama $\mathbb{D},{ }^{2}$ Daniel Saputra $\mathbb{D}^{2},{ }^{2}$ and Agus Wijaya ${ }^{2}$ \\ ${ }^{1}$ Department of Agriculture Product Technology, University of Lampung, Bandar Lampung 34145, Indonesia \\ ${ }^{2}$ Department of Agriculture Technology, University of Sriwijaya, Palembang 30662, Indonesia \\ Correspondence should be addressed to Maria Erna Kustyawati; maria.erna@fp.unila.ac.id
}

Received 19 April 2018; Revised 13 August 2018; Accepted 28 August 2018; Published 1 October 2018

Academic Editor: Vita Di Stefano

Copyright (c) 2018 Maria Erna Kustyawati et al. This is an open access article distributed under the Creative Commons Attribution License, which permits unrestricted use, distribution, and reproduction in any medium, provided the original work is properly cited.

\begin{abstract}
Application of supercritical carbon dioxide for processing of food products has an impact on microbial inactivation and food quality. This technique is used to preserve tempeh due to no heat involved. The quality of tempeh is highly influenced by mold growth because of its role in forming a compact texture, white color, and functional properties as well as consumer acceptance. This study aims to observe viability of molds and bacteria in tempeh after processed with supercritical $\mathrm{CO}_{2}$ and to determine the best processing conditions which can maintain mold growth and reduce the number of bacteria in tempeh. For that purpose, tempeh was treated using high pressure $\mathrm{CO}_{2}$ at $7.6 \mathrm{MPa}$ (supercritical $\mathrm{CO}_{2}$ ) and at $6.3 \mathrm{MPa}$ (sub/near supercritical $\mathrm{CO}_{2}$ ) with incubation period of $5,10,15$, and $20 \mathrm{~min}$. The best treatment obtained was used to process tempeh for storage study. The results showed that there was a significant interaction between pressure and incubation period for bacterial and mold viability at $\rho>0.05$. Reduction of bacteria and molds increased with longer incubation period. Molds were undetectable after treatment for 20 min with either supercritical $\mathrm{CO}_{2}$ or sub-supercritical, and bacteria significantly reduced up to $2.40 \mathrm{log} \mathrm{CFU} / \mathrm{g}$. On the other hand, sub-supercritical $\mathrm{CO}_{2}$ for $10 \mathrm{~min}$ was the best processing method because molds survived $4.3 \times 10^{4} \mathrm{CFU} / \mathrm{gram}$ after treatment and were able to grow during storage at $30^{\circ} \mathrm{C}$, producing white mycelium as indicated by increasing the $L *$ color value and tempeh acceptability. The inactivation of mold was reversible causing it to grow back during storage under suitable conditions. Tempeh matrix composition can provide protection against the destructive effects of supercritical $\mathrm{CO}_{2}$. Gram-positive bacteria were more resistant than Gram-negative. In conclusion, sub-supercritical $\mathrm{CO}_{2}$ can act as a method of cold pasteurization of tempeh and can be used as an alternative method to preserve tempeh.
\end{abstract}

\section{Introduction}

Consumer needs for food are not only in terms of health and food safety but also food with minimal processing that can maintain the quality of freshness and taste for a certain length of storage. Thermal food preservation is an effective technique for reducing microbial count of foods. However, for heat sensitive food products it can give undesirable sensorial changes and destroy the nutritional quality of the food. High pressure carbon dioxide technology is a nonthermal alternative processing to improve the microbial safety of the product while preserving nutritional and sensorial characteristics. It is known that carbon dioxide under the supercritical phase (7.4 M.Pa and $31.06^{\circ} \mathrm{C}$ ) has unique properties. Carbon dioxide has dual characteristics where it is like a gas with high diffusivity and a liquid with high solubility which enable it to easily diffuse through complex matrices and extract substances "Liao [1]". The supercritical $\mathrm{CO}_{2}\left(\mathrm{scCO}_{2}\right)$ characteristic has expanded its use for the inactivation of various vegetative microorganisms in food as a nonthermal technology without loss of taste, color, and nutrients "Calvo and Torres [2]". Sub-supercritical carbon dioxides (sub$\mathrm{scCO}_{2}$ ) treatment causes microbial inactivation and can avoid changes in sensory attributes of food quality. In relation to microbial growth and food processing, "Garcia-Gonzales [3]" and "Guo [4]" found that carbon dioxide can stimulate and inhibit cellular development, where inhibitory measures have been used to improve the hygiene of liquid and solid food by inactivating bacterial growth. The study conducted by "Kustyawati [5]" found that processing with supercritical 
$\mathrm{CO}_{2}$ and sub-supercritical $\mathrm{CO}_{2}$ retained the texture, vitamin $\mathrm{B}, \mathrm{Ca}$, and protein content, but reduced fat, water content, and some volatile compounds in tempeh.

Tempeh is generally sold in fresh form, even though it is not consumed in raw state, but needs to be processed further before consuming. Tempeh is a fermented soybean product by Rhizopus oligosporus, but bacteria and yeasts are also involved during the fermentation and contributed significantly to the production of functional metabolites. The microbial community structure in tempeh is a very important feature in maintaining not only the sensory appearance but also the functional nature of the tempeh. Supercritical carbon dioxide technology can be an alternative process for tempeh which is expected to reduce the number of bacteria and at the same time maintain high mold growth. The high number of bacteria in tempeh can interfere with mold growth and consequently the tempeh will spoil more quickly. Molds growth is needed to produce tempeh with a compact texture, white gray color, and being palatable. Previous research has shown that sub-supercritical $\mathrm{CO}_{2}$ at $6.3 \mathrm{MPa}$ for $10 \mathrm{~min}$ did not significantly affect tempeh color and the tempeh was acceptable "Kustyawati [5]". However, the survival of microorganisms in tempeh processed with supercritical $\mathrm{CO}_{2}$ has not been revealed. Minimal processing technology without involving heat that can maintain the growth of mold in tempeh is needed in an effort to increase the shelf-life and maintain the freshness of tempeh, nutritional value, and consumer preferences. The aim of this study was to observe viability of molds and bacteria in tempeh after processed with supercritical $\mathrm{CO}_{2}$ and determine best processing which can reduce bacteria but maintain mold life and to observe the ability of the mold to grow during storage.

\section{Materials and Methods}

2.1. Processing of Tempeh. The high pressure $\mathrm{CO}_{2}$ installation used for experimental treatments consists of a $\mathrm{CO}_{2}$ gas cylinder, a cylindrical pressure chamber, pressure gauges, and a water bath at constant temperature "Saputra [6]" (see Figure 1). Tempeh, in the form of cylinder with $3.5 \mathrm{~cm}$ in diameter and $10 \mathrm{~cm}$ in length, was obtained from the Center of Home Industry Tempeh Making Palembang, Indonesia. Fresh tempeh was placed in a pressure chamber and then closed tightly. When the designated temperature in water bath was reached and all pipe connections were secured, commercially available $\mathrm{CO}_{2}$ (PERTAMINA, Jakarta, Indonesia) was injected through the gas inlet valve from the gas cylinder into the pressure chamber until it reached the desired pressures of 6.3 and $7.6 \mathrm{MPa}$ (showed in pressure gauge) within $1 \mathrm{~min}$. After being subjected to high pressure $\mathrm{CO}_{2}$ treatment for the specified incubation period, the pressure was lowered to atmospheric pressure within 3 minutes by slowly opening the gas outlet valve. Then the tempeh was aseptically removed from the pressure chamber using a sterilized tong, placed in the sterilized container, and stored in a refrigerator before conducting the analysis such as SEM, but the samples were directly analyzed for microorganism analysis.

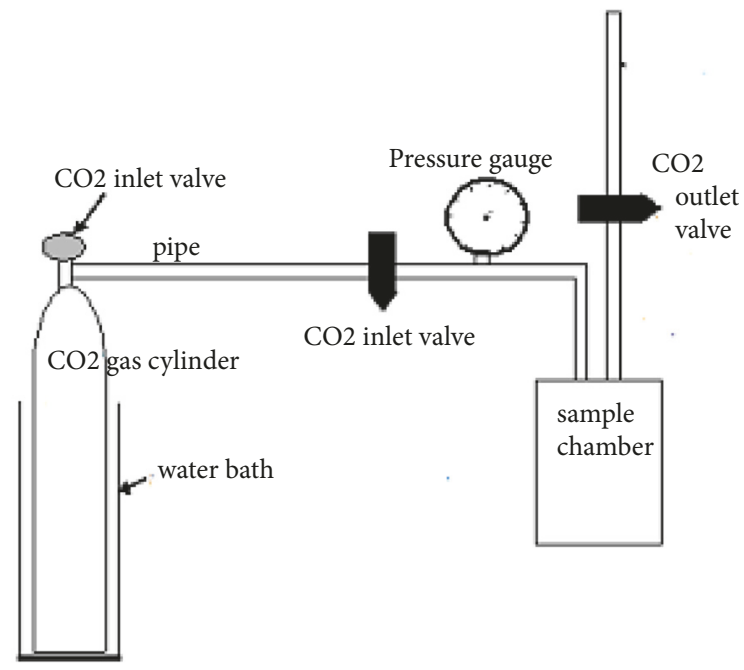

FIGURE 1: The diagram of the experimental apparatus.

The experiment was conducted in a full factorial design with the factors as follows: supercritical $\mathrm{CO}_{2}\left(\mathrm{scCO}_{2}\right)$ treatment at 7.6 $\mathrm{MPa}$ for 5, 10, 15, and $20 \mathrm{~min}$ and sub-supercritical $\mathrm{CO}_{2}$ (sub-scCO $)_{2}$ treatment at $6.3 \mathrm{MPa}$ for $5,10,15$, and 20 min. Each treatment was replicated three times.

2.2. Enumeration of Bacteria and Molds. The tempeh was plated no later than 1 hour after the processing. Samples (5 g) were homogenized (1:3) with phosphate buffer solution (BPS) in a Stomacher 400 for $1 \mathrm{~min}$, and appropriate dilutions of the homogenate were made. The enumeration of the bacteria in the Nutrient agar (NA Difco, USA) and molds in the potatoes dextrose agar (PDA, Difco USA) plates was done after incubation period $32^{\circ} \mathrm{C}$ for $24 \mathrm{~h}$ for bacterial and of $27^{\circ} \mathrm{C}$ for 4 days for molds counts. Oxytetracycline $0.05 \%$ and chloramphenicol $0.05 \%$ were added to the media to inhibit the growth of bacteria, and cyclohexemide $0.05 \%$ was added to inhibit the growth of yeasts. Results were reported as log $\mathrm{CFU} / \mathrm{g}$ for each treatment (CFU, colony forming units). The degree of inactivation was determined by evaluating the log (N/N0) versus time, where N0 (CFU/g) was the number of microorganisms initially present in the unprocessed sample and $\mathrm{N}(\mathrm{CFU} / \mathrm{g})$ was the number of survivors after the processing.

The surviving bacteria after supercritical $\mathrm{CO}_{2}$ processing were isolated and identified by the PCR sequencing analysis. The isolated strains were identified based on morphological characteristics, the biochemical profile according to the manufacturer's instructions (API system, Biomerieux, France), and sequencing $16 \mathrm{~S}$ (bacteria) $r \mathrm{DNA}$ as described below.

2.3. Analysis of DNA. The work of bacterial identification was done according to the method developed by "Parton [7]" as followed. To each of the isolates three to four colonies were picked up and suspended into $100 \mu \mathrm{L}$ of sterile $\mathrm{ddH}_{2} \mathrm{O}$ (double-distilled water). Extraction was done by heating at $100^{\circ} \mathrm{C}$ for $5 \mathrm{~min}$ to lyse the cells and centrifuged at 13.000 
$\mathrm{g}$ for $15 \mathrm{~min}$ at $4^{\circ} \mathrm{C}$. The supernatant which is containing DNA was transferred to an Eppendorf tube. Two $\mu \mathrm{L}$ of each DNA sample was used as a template in the Polymerase Chain Reaction assay. The primers 355F (5'-CCT ACG GGA GGC AGC AG-3') and 910r (5’ -CCC GTC AAT TCC GAG TT3') were used for bacterial cells. A final $50 \mu \mathrm{L}$ volume was used containing $5 \mu \mathrm{L}$ of forward primer $10 \mu \mathrm{m}$ (Sigma), $5 \mu \mathrm{L}$ of reverse primer $10 \mu \mathrm{m}$ (Sigma), $2 \mu \mathrm{L}$ of template DNA, $5 \mu \mathrm{L}$ of 10x Taq DNA polymerase buffer (Sigma), 4 $\mu \mathrm{L} \mathrm{MgCl}_{2}(25 \mathrm{~mm})$, and $0.5 \mu \mathrm{L}$ Taq DNA polymerase (5 $\mathrm{u} / \mu \mathrm{L}$, Sigma). The PCR conditions applied for bacteria were $95^{\circ} \mathrm{C}$ for $1 \mathrm{~min}$, followed by 30 cycles at $95^{\circ} \mathrm{C}$ for $30 \mathrm{sec}$, $50^{\circ} \mathrm{C}$ for $1 \mathrm{~min}$, and $72^{\circ} \mathrm{C}$ for $1 \mathrm{~min}$, followed by one final extension at $72^{\circ} \mathrm{C}$ for $6 \mathrm{~min}$. The Microcon PCR columns (Millipore, CA, USA) were used to purify the amplicons, and the purified products were eluted with $35 \mu \mathrm{L}$ of Milli$\mathrm{Q}$ sterile water. PCR sequencing reaction, which was of eight $n g$ of the DNA, was performed as follows: $3.2 \mu \mathrm{L}$ of forward primer $(1 \mu \mathrm{M}), 6 \mu \mathrm{L}$ of Big Dye Buffer (Applied Bio Systems), $2 \mu \mathrm{L}$ of Big Dye Mix (Terminator RR Mix, Applied Bio Systems), and Milli-Q sterile water up to $20 \mu \mathrm{L}$. The PCR conditions were followed as the one previously described. The extracted DNA was treated with $45 \mu \mathrm{L}$ of pure ethanol of $4^{\circ} \mathrm{C}$ and $3.75 \mu \mathrm{L}$ of EDTA of $125 \mu \mathrm{M}$, incubated in the dark for $15 \mathrm{~min}$, and centrifuged at $15,000 \mathrm{~g}$ for $15 \mathrm{~min}$ at $4^{\circ} \mathrm{C}$. The pellet obtained was washed with $150 \mu \mathrm{L}$ of $70 \%$ ethanol and again centrifuged at $15,000 \mathrm{~g}$ for $15 \mathrm{~min}$ at $4^{\circ} \mathrm{C}$. The pellets were dried for $15 \mathrm{~min}$ at $37^{\circ} \mathrm{C}$ and supernatants were discharged. The samples obtained were then suspended into the $15 \mu \mathrm{L}$ formamide and sequencing was carried out at an ABI PRISM 310 Genetic Analyzer (Perkin Elmer). For the identification, the sequences obtained were searched against and compared to those present in the National Center for Biotechnology Information (NCBI) genome bank. The similarity was determined by the percentage of similarity greater than $98.5 \%$.

2.4. Storage Study. The optimal condition of the process that was found in the experiment was used to treat the tempeh that would be used for storage study. Tempeh processed at the optimal process condition was stored at 20 and $30^{\circ} \mathrm{C}$ for 5 days, together with the unprocessed tempeh. During the storage, the total of molds and $L *$ color were analyzed daily. A storage time of 5 days was chosen considering that the shelf-life of fresh tempeh is normally around 1-2 days at room temperatures $\left(30 \pm 2^{\circ} \mathrm{C}\right)$, while processing of sub- $\mathrm{scCO}_{2}$ was expected to extend the shelf-life of the tempeh.

2.5. Color Measurement. The surface color analysis of processed and unprocessed tempeh was evaluated as CIE $L * a * b *$ value and $L C H$ color scale using color difference meter (TC-1500, Tokyo, Japan). Results were expressed as $L *$ (Lightness), $a *$ (redness), and $b *$ (yellowness). The $L *, a *$, and $b *$ values represent the means of the three measurements for each sample. The total color difference $(\Delta E *)$ between the control and the treated tempeh was obtained using the following equation: $\Delta E^{*}=\sqrt{\Delta L *^{2}+\Delta a *^{2}+\Delta b *^{2}}$ where the $\Delta L *, \Delta a *$, and $\Delta b *$ values meant the difference between the $L *, a *$, and $b *$ values after the treatment and the $L *$, $a *$, and $b *$ values of the standard color. The standard color used in this experiment was the $L *, a *$, and $b *$ values of the tempeh control.

2.6. Scanning Electron Microscope (SEM). Analysis microstructure of tempeh mycelium microstructure was conducted by scanning electron microscope (SEM JEOL JSM 5310 LV) following "Hong and Pyun [8]" procedures adjusted to tempeh sample. Sample preparation procedures before being observed with SEM were as follows: (1) tempeh was cut according to the $s t u b$ size and affixed to the top of the $s t u b,(2)$ then tempeh was coated with gold by using IB2 ion coater tool for 5 minutes with ions current of 6-8 miliAmpere, and (3) finally tempeh was observed with ACC $20 \mathrm{kV}$-voltage devices at $2000 \mathrm{x}, 3000 \mathrm{x}$, and $10000 \mathrm{x}$ magnification.

2.7. Statistical Analysis. Statistically significant differences $(\rho<0.05)$ between the two types of treatment were determined using analysis of variance (ANOVA) and Duncan's multiple range tests "Gomez and Gomez [9]".

\section{Results and Discussion}

3.1. Bacterial and Mold Inactivation. The study showed that there was a significant interaction with pressure and holding time for bacteria and molds inactivation at $\rho>0.05$ (see Table 1). The initial bacterial and the mold counts were $2.3 \times 10^{7} \mathrm{CFU} / \mathrm{g}$ and $6,1 \times 10^{6} \mathrm{CFU} / \mathrm{g}$, respectively. The number of bacteria and molds decreased with increasing pressure and time period applied. Molds were more affected than bacteria (Figure 2). Bacterial number decreased to about 1.7 logs at supercritical $\mathrm{CO}_{2}$ and 1.08 logs at sub-supercritical $\mathrm{CO}_{2}$ while molds decreased to about 4.88 logs at supercritical $\mathrm{CO}_{2}$ and 3.73 logs at sub-supercritical $\mathrm{CO}_{2}$. It is suggestive that the inactivation process was not caused by the pressure of pressurized $\mathrm{CO}_{2}$. Inactivation process occurred at either sub/near supercritical $\mathrm{CO}_{2}$ or supercritical $\mathrm{CO}_{2}$. In some studies such as Kimchi processing, the inactivation of microorganisms was achieved at very high $\mathrm{CO}_{2}$ pressures, namely, $600 \mathrm{MPa}$, compared to the inactivation process only at the pressure of 6.3 and $7.6 \mathrm{MPa}$ in this study. The decrease in the number of microorganisms at elevated pressurized $\mathrm{CO}_{2}$ can be explained as high solvating power of supercritical $\mathrm{CO}_{2}$ extract vital constituents from the cells or cell membranes, resulting in death of the cell. In this case, pressurized $\mathrm{CO}_{2}$ penetrates into the cells to build up the density within the cells and expand the cell wall, then it removes intracellular constituent including phospholipids and hydrophobic compounds when the pressure is suddenly released. The removals of constituents alter the structure of the membranes and the balance of the biological system promoting inactivation.

Figure 2 showed that bacteria decreased up to 2.4 logs at supercritical $(7.6 \mathrm{MPa}) \mathrm{CO}_{2}$ for $20 \mathrm{~min}$, whereas they decreased to 1.5 logs at sub-supercritical (6.3 $\mathrm{MPa}) \mathrm{CO}_{2}$ for $20 \mathrm{~min}$. In contrast to our study, "Ferrentino [10]" was reported that the optimal conditions to obtain about 3.0, 1.6, and $2.5 \log (\mathrm{CFU} / \mathrm{g})$ reductions of mesophilic aerobic, 
TABLE 1: Interaction of high pressure $\mathrm{CO}_{2}$ processing and time period on the inactivation of bacteria and molds in tempeh.

\begin{tabular}{lcc}
\hline Treatments: pressures/time periods & Bacterial reduction log N/No & Mold reduction log N/No \\
\hline $\mathrm{scCO}_{2} / 5 \mathrm{~min}$ & $0.54 \pm 0.52^{\mathrm{b}}$ & $2,33 \pm 0.15^{\mathrm{c}}$ \\
$\mathrm{scCO}_{2} / 10 \mathrm{~min}$ & $1.54 \pm 0.22^{\mathrm{e}}$ & $4,23 \pm 0.02^{\mathrm{d}}$ \\
$\mathrm{scCO}_{2} / 15 \mathrm{~min}$ & $2.34 \pm 0.12^{\mathrm{f}}$ & $6,47 \pm 0.11^{\mathrm{f}}$ \\
$\mathrm{scCO}_{2} / 20 \mathrm{~min}$ & $2.40 \pm 0.13^{\mathrm{f}}$ & $6,53 \pm 0.52^{\mathrm{f}}$ \\
$\mathrm{sub} \mathrm{scCO} / 5 \mathrm{~min}$ & $0.30 \pm 0.12^{\mathrm{a}}$ & $1,17 \pm 0.12^{\mathrm{a}}$ \\
sub scCO$/ 10 \mathrm{~min}$ & $1.10 \pm 0.13^{\mathrm{c}}$ & $1,93 \pm 0.20^{\mathrm{b}}$ \\
sub scCO$/ 15 \mathrm{~min}$ & $1.40 \pm 0.11^{\mathrm{d}}$ & $5,27 \pm 0.07^{\mathrm{e}}$ \\
sub scCO$/ 20 \mathrm{~min}$ & $1.50 \pm 0.23^{\mathrm{e}}$ & $6,47 \pm 0.41^{\mathrm{f}}$ \\
\hline
\end{tabular}

Note: the numbers in the column followed by the same letter were not significantly different under $p 0.05$.

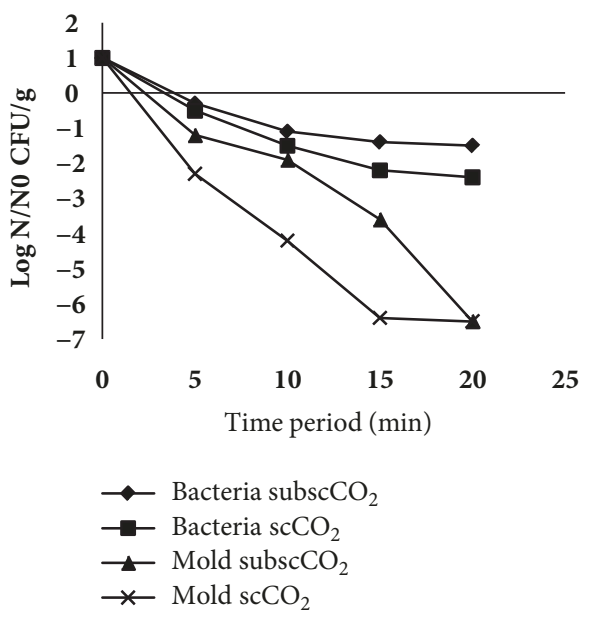

Figure 2: The effect of supercritical (7.6 MPa) and sub-supercritical $\mathrm{CO}_{2}(6.3 \mathrm{MPa})$ processing on bacterial and mold inactivation.

psychrophilic, and lactic acid bacteria in cubed cooked ham were $\mathrm{scCO}_{2}$ processing at $12 \mathrm{MPa}, 50^{\circ} \mathrm{C}, 5 \mathrm{~min}$. "Gunes [11]" demonstrated that supercritical $\mathrm{CO}_{2}$ at $8 \mathrm{MPa}$ can be an effective nonthermal alternative process for pasteurization of grape juice and tomato paste. The inactivation process of microorganisms in tempeh increased in relation to the increase of incubation period of pressurized $\mathrm{CO}_{2}$ (see Table 1). Increase in incubation period from 5 to $20 \mathrm{~min}$ showed a significant increase in the inactivation values of bacteria and molds where bacterial population decreased from 0.42 to 1.95 logs and molds decreased from 1.75 to 6.5 logs. The explanation to this was that mass transfer rate of $\mathrm{CO}_{2}$ was greater with the longer incubation period of the pressure of pressurized $\mathrm{CO}_{2}$. At longer incubation period the amount of $\mathrm{CO}_{2}$ increases, accumulates into the lipophilic inner layer, and dissolves into and forms hydrogen bond with phospholipid "Mulakhudair [12]", resulting in destruction to cell structure and function due to breakdown of lipid chains. This will further increase the permeability of cell membrane, making it easier for $\mathrm{CO}_{2}$ to enter the cytoplasm cell. In the cytoplasm $\mathrm{CO}_{2}$ binds to water and forms $\mathrm{HCO}_{3}{ }^{-}$ions, lowering the cytosolic $\mathrm{pH}$ which interferes with cell metabolic processes and results in cell death "Garcia-Gonzales [13]".
At the increased pressure and time, molds inactivation increased (see Figure 2). Molds decreased to an undetectable number $(\log 6)$ for $20 \mathrm{~min}$ at sub-supercritical $\mathrm{CO}_{2}(6.3 \mathrm{MPa})$ and $15 \mathrm{~min}$ at supercritical $\mathrm{CO}_{2}(7.6 \mathrm{MPa})$. However, it was found that the countable numbers of molds were $4.3 \times 10^{4}$ $\mathrm{CFU} / \mathrm{g}$ at the tempeh processed with sub/near supercritical $\mathrm{CO}_{2}$ for $10 \mathrm{~min}$, indicating processing under these conditions is optimal to be applied to tempeh because there are still a number of fungal growths on the surface of tempeh at $10^{4}$ $\mathrm{CFU} / \mathrm{g}$. This is supported by the fact that the mycelium was inflated (see Figure 3(b)). Hyphae mycelium (tempeh control) without inactivation process showed an elastic-rigid texture while mycelium after the inactivation process at $6.3 \mathrm{MPa}$ for 10 min showed that hyphae was inflated (see Figure 3(a)). The minimum number of molds is $10^{3} \mathrm{CFU} / \mathrm{g}$ for tempeh to have a compact structure, produce grayish white color, have a functional role, and be accepted by consumers "Kustyawati".

This finding was in contrast with published data by "Shon and Lee [14]" where molds remained relatively constant in Kimchi after treatment up to $600 \mathrm{MPa}$. Other finding showed that yeasts and molds were undetected in herbs dried with supercritical $\mathrm{CO}_{2}$ at $10 \mathrm{MPa}$ for $150 \mathrm{~min}$ "Zambon [15]" which was in agreement with our results. The type and chemical contents of products processed with the supercritical $\mathrm{CO}_{2}$ could be the reason for differences in findings. During high pressure processing in this experiment, $\mathrm{CO}_{2}$ diffused easily into the tempeh matrix because the tempeh contains soluble proteins, fat, carbohydrates, and other polar compounds. The interaction between $\mathrm{CO}_{2}$ and matrix macromolecules caused changes in the matrix structure, providing protection for microorganisms in tempeh. In addition, the penetration of $\mathrm{CO}_{2}$ into the hyphae caused the cell to be inflated which was reversible due to its elastically rigid texture, comprising a double layer of glycoprotein, glucan, chitin, and melanin "Madigan [16]".

The number and type of microorganisms present in tempeh depend on the inoculums used in fermentation and fermentation process conditions. Tempeh is a fresh food with water content ranging from 65 to $65.7 \%$ (dry weight) "Kustyawati [5]". When tempeh is processed with supercritical $\mathrm{CO}_{2}$, water in contact with pressurized $\mathrm{CO}_{2}$ becomes acidic due to the formation and dissociation of $\mathrm{H}_{2} \mathrm{CO}_{3}$ which liberates $\mathrm{H}^{+}$ions, resulting in lowering $\mathrm{pH}$ in the tempeh ( $\mathrm{pH}$ of extracellular). Even though this low $\mathrm{pH}$ may diminish 


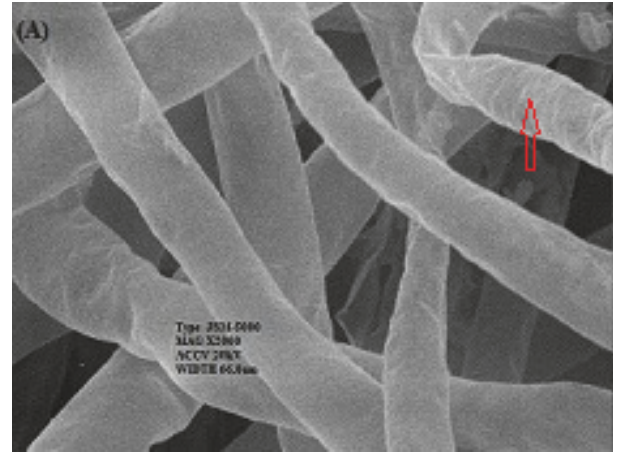

(a)

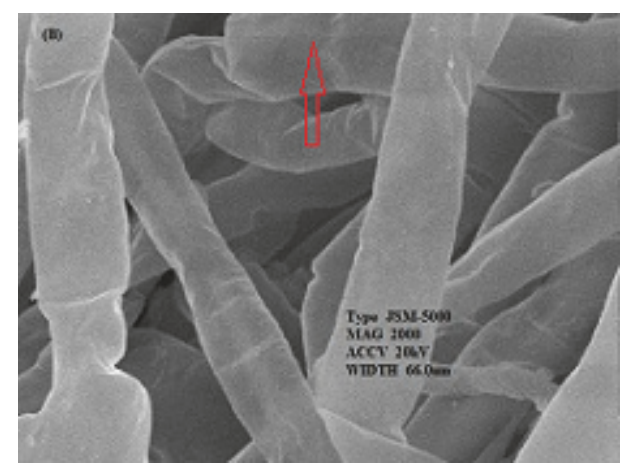

(b)

FIGURE 3: The changes of hyphae mycelium. (a) Hyphae were elastically rigid before the inactivation process at $6.3 \mathrm{MPa}$ for $10 \mathrm{~min}$. (b) Hyphae were inflated after the inactivation process at $6.3 \mathrm{Mpa}$ for $10 \mathrm{~min}$.

resistance to inactivation of microorganisms, the reduction in $\mathrm{pH}$ is not enough to cause the lethal effect of $\mathrm{CO}_{2}$ on some bacteria in the tempeh. Therefore in this experiment, Bacillus subtilis, Lactobacillus sp., Pediococcus sp., and Streptococcus sp. were found and isolated from tempeh after processed with pressurized $\mathrm{CO}_{2}$ with the pressure of $7.8 \mathrm{MPa}$ for $20 \mathrm{~min}$. In addition to these bacteria, Klebsiella pneumonia, Citrobacter freundii, and Enterobacter cloacae were also found from tempeh without processing. This finding was in agreement with the published data "Mathias [17]" that supercritical $\mathrm{CO}_{2}$ exposure to Bacillus subtillis ranging from 2 to $25 \mathrm{MPa}$ did not influence its inactivation. Another study reported that application of high pressure $\mathrm{CO}_{2}$ ranging from 200 to 600 MPa resulted in more than $99.99 \%$ of cells which were sublethally injured "Ulmer [18]". Lowered pH of the tempeh may contribute to an increase in cell permeability which facilitates penetration of $\mathrm{CO}_{2}$ into microbial cell and accumulates in the cytoplasmic interior of bacterial cell. Cell walls of Gramnegative bacteria are composed of lipopolysaccharide on the outside and a thin layer of peptidoglycan in the inside. Supercritical $\mathrm{CO}_{2}$ has hydrophobic properties, which can penetrate the cell wall, and dissolves lipopolysaccharide layer. If too much amount of dissolved $\mathrm{CO}_{2}$ enters the cytoplasm, the cell may be unable to maintain the $\mathrm{pH}$ homeostasis and $\mathrm{pH}$ of the internal cell will begin to decrease to coincide with disruption of cellular activity and result in the cell death "Dillows [19]". This likely is the reasons of the lethal effect on Gram-negative bacteria in tempeh, whereas it is possible that the resistance of Gram-positive bacteria is due to high impermeability of their cell membrane owing to the thick layers rich of peptidoglycan and basic protein, and thin layer of phospholipid-content, resulting in the limited penetration of $\mathrm{CO}_{2}$.

3.2. Storage Study. It was found that the best processing condition was sub/near supercritical $\mathrm{CO}_{2}$ for $10 \mathrm{~min}$. For the storage study, tempeh was processed with sub-supercritical $\mathrm{CO}_{2}$ for $10 \mathrm{~min}$ and then stored at temperature of $20^{\circ} \mathrm{C}$ and $30^{\circ} \mathrm{C}$. The initial number of molds was $2.5 \times 10^{6} \mathrm{CFU} / \mathrm{g}$ before storage and slightly increased during 3 days of storage at $30^{\circ} \mathrm{C}$. Relationship between countable mold and storage time showed that the molds increased at a storage temperature of $30^{\circ} \mathrm{C}$ but decreased at a temperature of $20^{\circ} \mathrm{C}$ (see Figure 4 ). High $\mathrm{CO}_{2}$ concentration increases the acidity of the medium because $\mathrm{CO}_{2}$ reacts with water in the tempeh matrix and produces carbonic acid. Carbonic acid is a weak acid which dissociates to produce $\mathrm{H}^{+}$ions so that the acidity of tempeh ( $\mathrm{pH}$ of the tempeh in this study was 5.9-6.1) is favored by molds for their growth, beside optimal growth of mold is at $30^{\circ} \mathrm{C}$. This may explain why mold can grow during the storage process.

Fresh tempeh has bright white color produced by the growth of mold, Rhizopus oligosporus. The brightness of color in tempeh is measured using $L *$ value. Tempeh which has a brownish yellow color indicates that the tempeh has been spoilage, and tempeh that has a dark color produced by spores shows that the tempeh undergoes overfermentation. The color changes in tempeh are caused by, for example, damage to the mycelium of $R$. oligosporus, increased concentration of soy color in a particular area, occurrence of other reactions in tempeh, and spore formations. The $L *$ color kinetic value was showed in Figure 5. High $L *$ (lightness) values showed the whitest bright color of fresh tempeh, while low $L *$ value showed the dark brown color of spoilage tempeh. Compared with unprocessed tempeh, $L *$ color of the processed tempeh showed a slight increase during storage. The $L *$ value of processed tempeh increased after day 1 at the level of 0.94 while it slightly decreased on storage of $20^{\circ} \mathrm{C}$ at the -3.42 level. Meanwhile, the $L *$ value of unprocessed tempeh showed a rapid decline from the first day of storage at the level of -10.3 to -14.0 . An increase of $L *$ value indicated that there was a growing mold. Similar results were reported by "Ferrentino [20]" who observed a significant reduction in color lightness and redness for untreated samples of cloudy apple juice while samples treated with supercritical $\mathrm{CO}_{2}$ appeared to have a smaller change when compared with untreated ones. "Kincal [21]" provides that orange juice treated with a continuous high pressure carbon dioxides (HPCD) system has higher lightness and yellowness when compared with untreated samples during storage. 


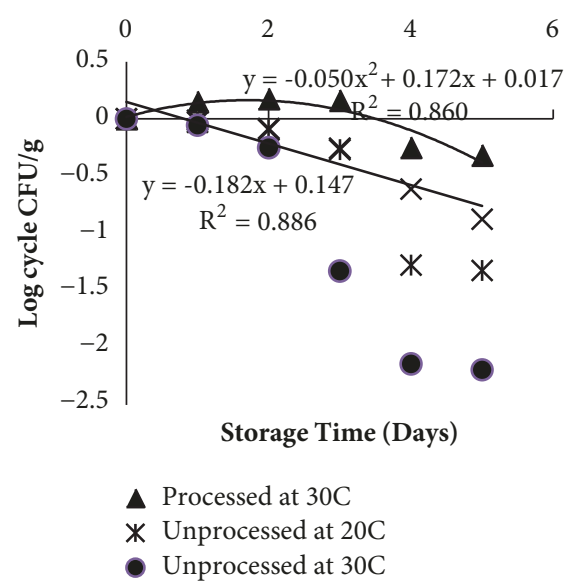

Figure 4: The relationship between mold abundance and storage time at 20 and $30^{\circ} \mathrm{C}$ of processed tempeh.

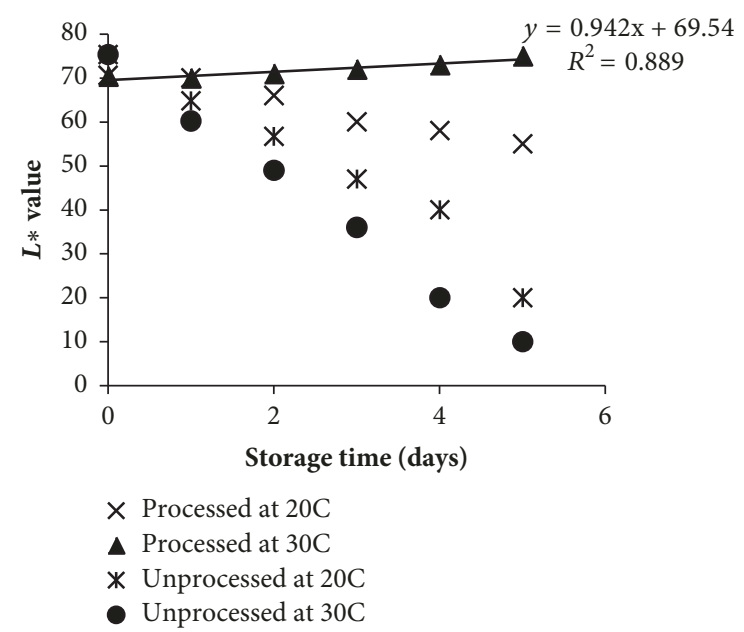

FIgURE 5: Effect of sub-supercritical $\mathrm{CO}_{2}$ on the change of lightness $(L *)$ during storage at 20 and $30^{\circ} \mathrm{C}$.

\section{Conclusions}

Tempeh was used as a model for food product processed with supercritical $\mathrm{CO}_{2}$. Ratio of survivor microorganisms (bacteria and molds) in tempeh after each treatment was calculated after spread plating the bacteria and molds in nutrient agar and potatoes dextrose agar plates, respectively. There was a significant interaction with the pressure and incubation period for bacterial and molds reduction at $\rho>0.05$. Reduction of bacteria and molds increased with longer incubation time. Reduction of bacteria $1.5 \mathrm{log}$ was achieved after treatment with supercritical $\mathrm{CO}_{2}$ for $10 \mathrm{~min}$ and sub-supercritical $\mathrm{CO}_{2}$ for $20 \mathrm{~min}$, while mold reduced 6.0 logs after treatment for $20 \mathrm{~min}$ with either supercritical or sub-supercritical $\mathrm{CO}_{2}$. The longer incubation period may influence microbial reduction in tempeh. Composition of tempeh matrix may give protection against destructive effect of supercritical $\mathrm{CO}_{2}$. Gram-negative bacteria in tempeh were dying but Gram-positive bacteria were more resistant to supercritical $\mathrm{CO}_{2}$. The inactivation of mold was reversible causing it to grow back during storage under suitable conditions. Therefore, processing with sub/near supercritical $\mathrm{CO}_{2}$ for $10 \mathrm{~min}$ was the best method to apply to tempeh because molds survived up to $4.3 \times 10^{4} \mathrm{CFU} / \mathrm{g}$ and bacteria reduced 1.1 logs, and tempeh is still acceptable to consumer. The treatment can act as a method of cold pasteurization of tempeh and can be an alternative method to preserve tempeh.

\section{Data Availability}

The data used to support the findings of this study are available from the corresponding author upon request.

\section{Disclosure}

This work referred to the abstract published in https:// waset.org/abstracts/nutrition-and-food-engineering/50233.

\section{Conflicts of Interest}

The authors declare that there are no conflicts of interest regarding the publication of this work.

\section{Acknowledgments}

The author would like to acknowledge the Ministry of Research, Technology and Higher Education of The Republic of Indonesia for partly funding this research.

\section{References}

[1] H. Liao, L. Zhang, X. Hu, and X. Liao, "Effect of high pressure $\mathrm{CO} 2$ and mild heat processing on natural microorganisms in apple juice," International Journal of Food Microbiology, vol. 137, no. 1, pp. 81-87, 2010.

[2] L. Calvo and E. Torres, "Microbial inactivation of paprika using high-pressure CO2," The Journal of Supercritical Fluids, vol. 52, no. 1, pp. 134-141, 2010.

[3] L. Garcia-Gonzalez, A. H. Geeraerd, S. Spilimbergo et al., "High pressure carbon dioxide inactivation of microorganisms in foods: The past, the present and the future," International Journal of Food Microbiology, vol. 117, no. 1, pp. 1-28, 2007.

[4] M. Guo, J. Wu, Y. Xu, G. Xiao, M. Zhang, and Y. Chen, "Effects on microbial inactivation and quality attributes in frozen lychee juice treated by supercritical carbon dioxide," European Food Research and Technology, vol. 232, no. 5, pp. 803-811, 2011.

[5] M. Erna Kustyawati, F. Pratama, D. Saputra, and A. Wijaya, "Modification of texture, color and aroma of tempeh after being process with supercritical CO2," Jurnal Teknologi dan Industri Pangan, vol. 25, no. 2, pp. 168-175, 2014.

[6] D. Saputra, F. A Payne, and P. L. Cornelius, "Puffing degydrated green bell pappers with CO2," American Society of Agricultural and Biological Engineers, 1991.

[7] T. Parton, A. Bertucco, and G. Bertoloni, "Pasteurisation of grape must and tomato paste by dense-phase $\mathrm{CO} 2$," Italian Journal of Food Science, vol. 19, no. 4, pp. 425-437, 2007.

[8] S. Hong and Y. Pyun, "Inactivation Kinetics of Lactobacillus plantarum by High Pressure Carbon Dioxide," Journal of Food Science, vol. 64, no. 4, pp. 728-733, 1999. 
[9] G. H. Freeman, K. A. Gomez, and A. A. Gomez, "Statistical Procedures for Agricultural Research with Emphasis on Rice.," Biometrics, vol. 34, no. 4, p. 721, 1978.

[10] G. Ferrentino, S. Balzan, and S. Spilimbergo, "Optimization of supercritical carbon dioxide treatment for the inactivation of the natural microbial flora in cubed cooked ham," International Journal of Food Microbiology, vol. 161, no. 3, pp. 189-196, 2013.

[11] G. Gunes, L. K. Blum, and J. H. Hotchkiss, "Inactivation of yeasts in grape juice using a continuous dense phase carbon dioxide processing system," Journal of the Science of Food and Agriculture, vol. 85, no. 14, pp. 2362-2368, 2005.

[12] A. R. Mulakhudair, M. Al-Mashhadani, J. Hanotu, and W. Zimmerman, "Inactivation combined with cell lysis of Pseudomonas putida using a low pressure carbon dioxide microbubble technology," Journal of Chemical Technology and Biotechnology, vol. 92, no. 8, pp. 1961-1969, 2017.

[13] L. Garcia-Gonzalez, A. H. Geeraerd, J. Mast et al., "Membrane permeabilization and cellular death of Escherichia coli, Listeria monocytogenes and Saccharomyces cerevisiae as induced by high pressure carbon dioxide treatment," Food Microbiology, vol. 27, no. 4, pp. 541-549, 2010.

[14] S. Kyung-Hyun and L. H-Joo, Effect of high pressure treat, no. 359-365, 1998.

[15] A. Zambon, F. Michelino, S. Bourdoux et al., "Microbial inactivation efficiency of supercritical CO2 drying process," Drying Technology, pp. 1-6, 2018.

[16] M. T. Madigan, J. M. Martinko, and D. A. Stahl, Brock Biology of Microorganisms, Pearsons Education Inc, San Fransisco, 2012.

[17] O. Mathias, T. Kablan, and A. Joseph, "Inactivation of Bacillus Subtilis spores with pressurized CO2and influence of O2, N2O and $\mathrm{CH} 2 \mathrm{CH} 2 \mathrm{OH}$ on its sporicidal activity," European Journal of Scientific Research, vol. 40, no. 1, pp. 6-14, 2010.

[18] H. M. Ulmer, M. G. Ganzle, and R. F. Vogel, "Effects of high pressure on survival and metabolic activity of Lactobacillus plantarum TMW1.460," Applied and Environmental Microbiology, vol. 66, no. 9, pp. 3966-3973, 2000.

[19] A. Dillow, F. Dehghani, and J. S. Hrkah, "Bacterial inactivation by using near-and supercritical CO2," Proceedings of the National Academy of Sciences of the United States of America, vol. 96, no. 18, pp. 10344-10348, 2008.

[20] G. Ferrentino, M. Bruno, G. Ferrari, M. Poletto, and M. O. Balaban, "Microbial inactivation and shelf life of apple juice treated with high pressure carbon dioxide," Journal of Biological Engineering, vol. 3, 2009.

[21] D. Kincal, W. Hill, M. Balaban et al., "A Continuous HighPressure Carbon Dioxide System for Cloud and Quality Retention in Orange Juice," Journal of Food Science, vol. 71, no. 6, pp. C338-C344, 2006. 


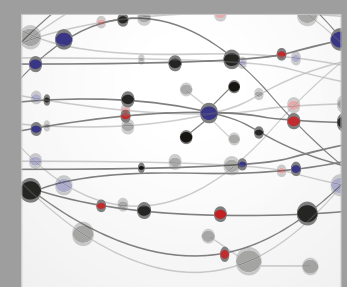

The Scientific World Journal
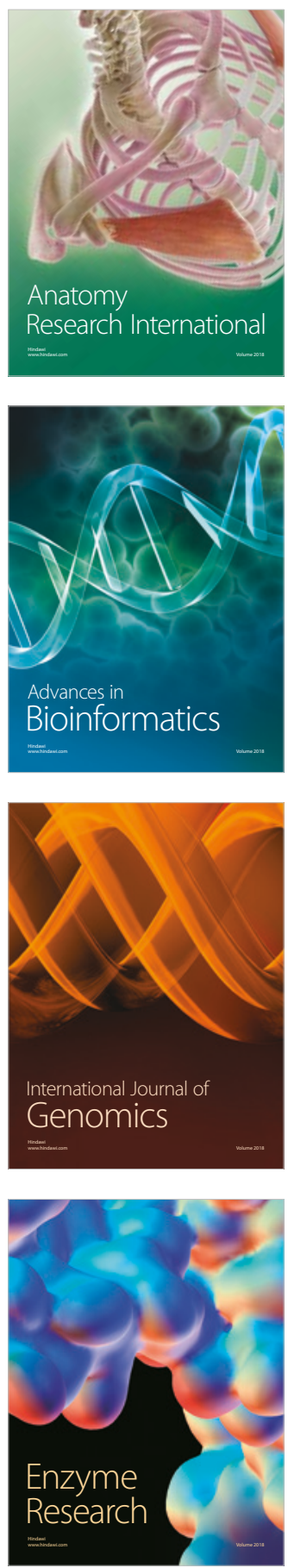
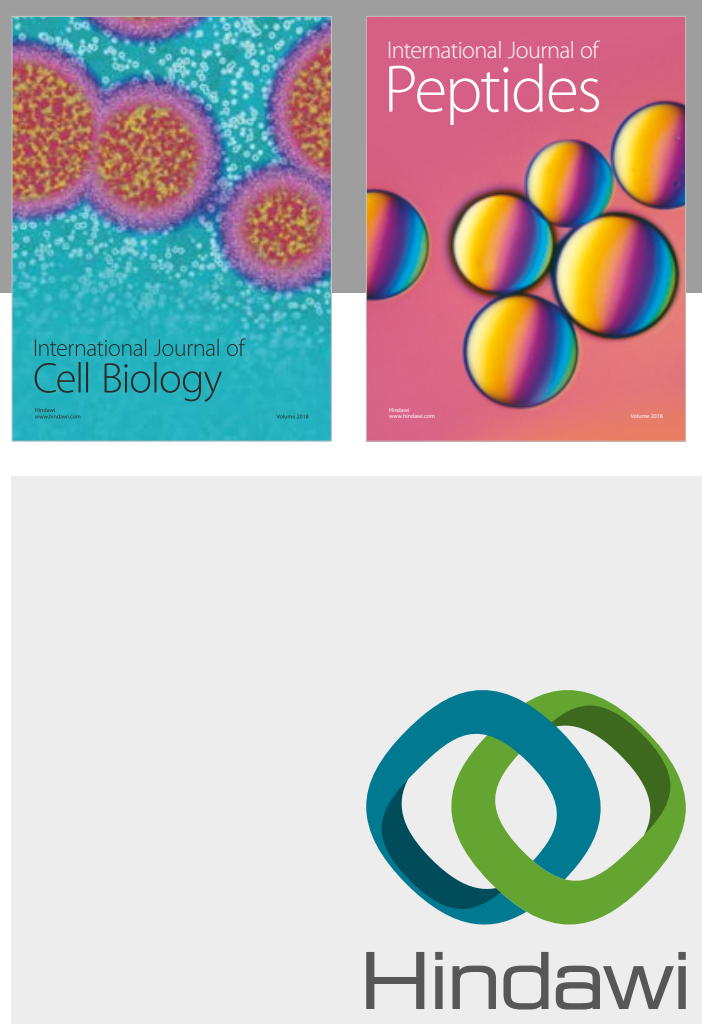

Submit your manuscripts at

www.hindawi.com
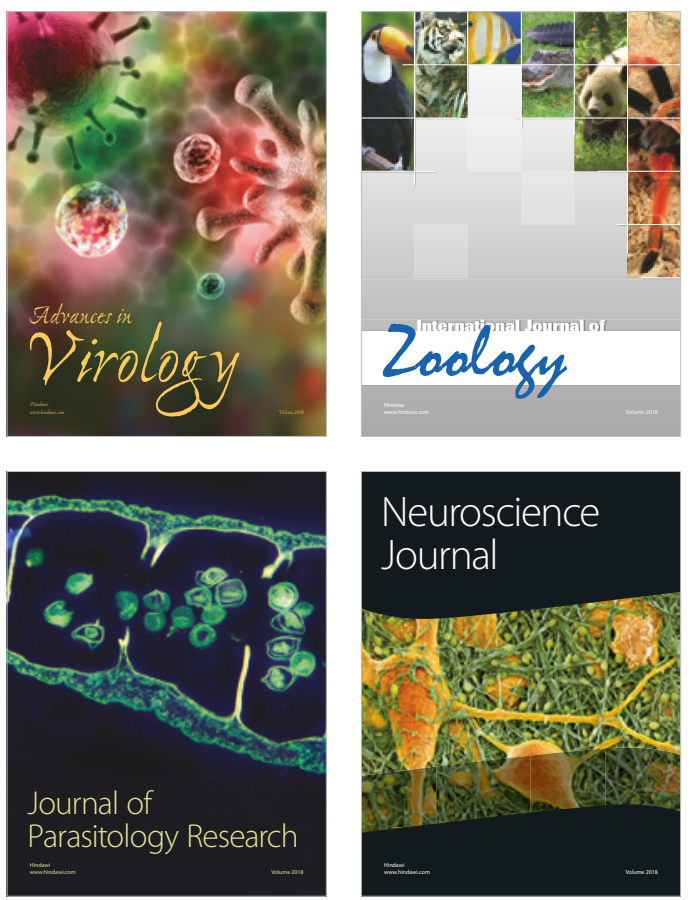
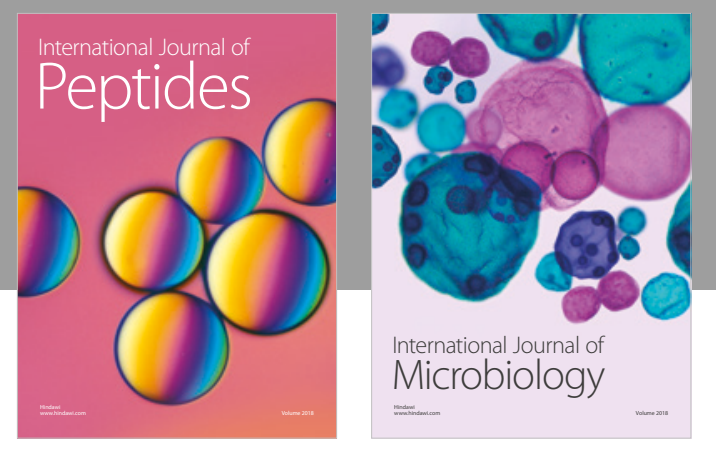

nternational Journal of Microbiology
Journal of
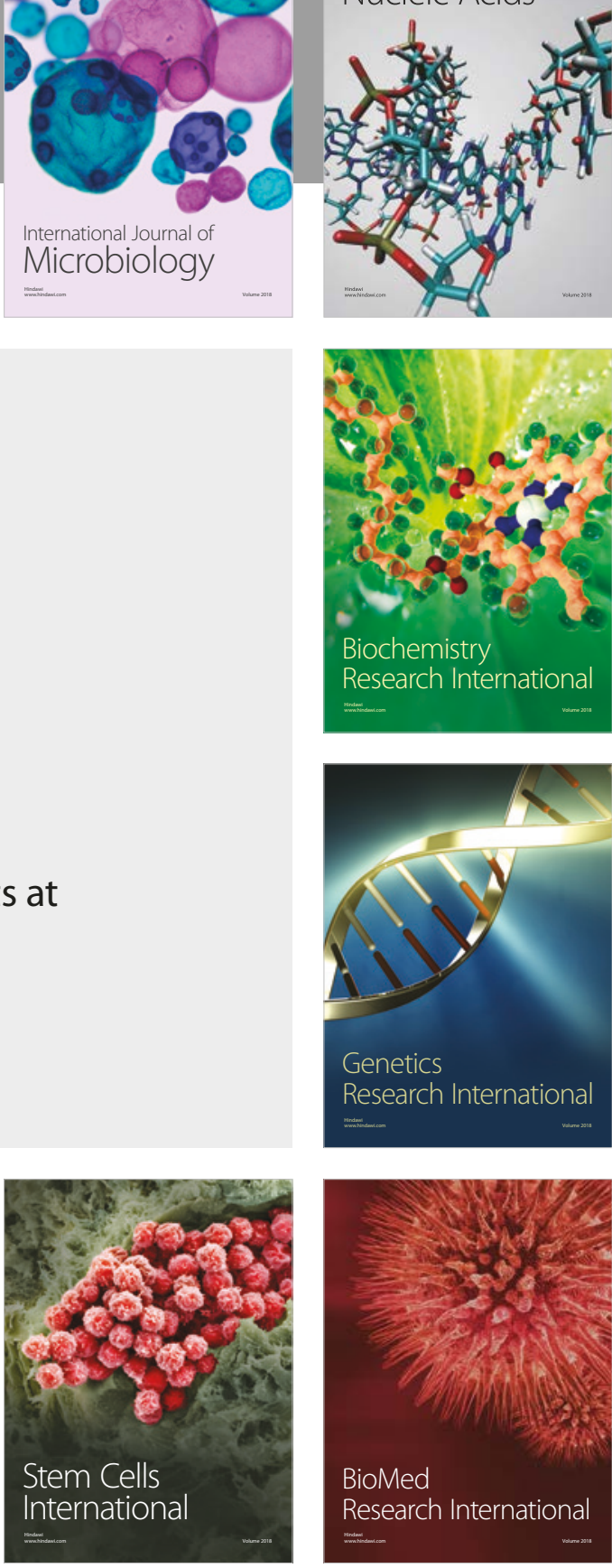
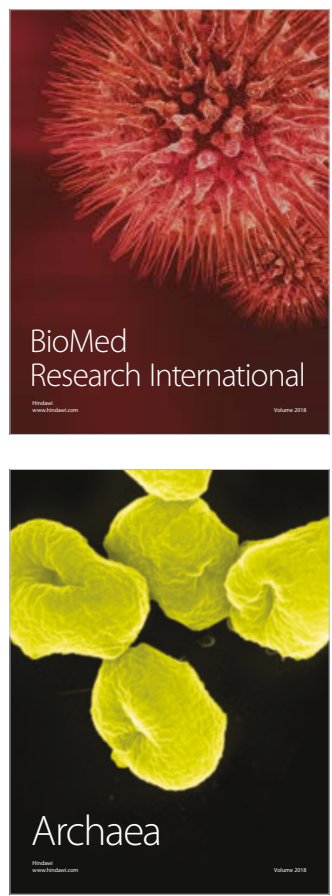